\title{
Mice Cloned by Nuclear Transfer from Somatic and ntES Cells Derived from the Same Individuals
}

\author{
Sayaka WAKAYAMA ${ }^{1,2)}$, Eiji MIZUTANI 1,3), Satoshi KISHIGAMI1), \\ Nguyen Van THUAN ${ }^{1}$, , Hiroshi OHTA ${ }^{1)}$, Takafusa HIKICHI ${ }^{1}$, \\ Hong Thuy BUI ${ }^{1)}$, Masashi MIYAKE ${ }^{2)}$ and Teruhiko WAKAYAMA ${ }^{1)}$ \\ ${ }^{1)}$ Center for Developmental Biology, RIKEN Kobe, 2-2-3 Minatojima-minamimachi, Kobe \\ 650-0047, ${ }^{2)}$ Department of Life Science, Graduate School of Science and Technology, Kobe \\ University, Kobe 657-8501, and ${ }^{3)}$ Graduate School of Agricultural Science, Tohoku \\ University, Sendai 981-8555, Japan
}

\begin{abstract}
The current success rate of cloned mice from adult somatic cell nuclei is very low, whereas it is relatively high for cloned mice from ES cell nuclei. In this experiment, we examined whether the success rate of cloning from somatic cells could be improved via nuclear transfer embryonic stem cells (ntES cells) established from somatic cell nuclei. We obtained 11 cloned mice and $68 \mathrm{ntES}$ cell lines from the somatic cell nuclei of 7 mice, and cloned 41 mice were cloned from the ntES cell nuclei. Unexpectedly, the overall success rate of cloning from ntES cell nuclei in this series was no better than when using somatic cell nuclei. Interestingly, full-term cloned mice were produced only via ntES cells from two individuals, but not by direct nuclear transfer from the somatic cells, and vice versa. Ultimately, we were able to obtain clone mice from 6 out of 7 individuals using either somatic cells or ntES cells. Thus, although ntES cells as donor nuclei do not absolutely assure a better success rate for mouse cloning than somatic cells, to preserve and clone valuable individuals, we recommend that ntES cell lines be established. These can then be used as an unlimited source of donor nuclei for nuclear transfer, and thus complement conventional somatic cell nuclear transfer cloning approaches. Key words: Clone, ntES cell, Nuclear transfer, Reprogramming
\end{abstract}

(J. Reprod. Dev. 51: 765-772, 2005)

C loning mammals by nuclear transfer began more than 20 years ago [1], yet the biology underlying this process remains obscure. We previously developed a microinjection-based nuclear transfer method to generate cloned mice from adult cumulus cells [2,3] and from tail-tip cells [4]. Ogura et al. have reported success in cloning mice from Sertoli cells [5], natural killer T cells [6], and primordial germ cells [7]. However, as with other mammals, the overall efficiency of mouse cloning (the percentage of activated oocytes

Accepted for publication: September 9, 2005

Published online: October 14, 2005

Correspondence: T. Wakayama (e-mail: teru@cdb.riken.jp) giving rise to live offspring) in all reports is less than $2 \%$. Cloned embryos generally grow to the blastocyst stage, but then fetal developments tend to arrest, with a failure to establish normal placental tissues, presumably because of impaired genomic reprogramming. We previously showed that the donor strain [8] and treatment of dimethyl sulfoxide (DMSO) are important determinants of cloning efficiency $[8,9]$. However, the technical variations that have been isolated so far apparently do not exert a marked influence on the efficiency of cloning. These include the methods of oocyte activation [10], timing of oocyte activation [9], inhibition of cytokinesis [9], and timing of 
enucleation or injection of the nucleus [11].

By contrast, the successful rate of cloning was higher when embryonic stem (ES) cells from the fertilized blastocyst were used as a source of donor nuclei than when somatic cells were used directly $[12,13]$. As with somatic cells, success depended on the background genotype of the ES cells $[8,14]$; thus $5 \%-10 \%$ of cloned blastocysts produced using the nuclei of F1 generation ES cells developed to full-term mice $[12,13]$. ES cells are pluripotent (capable of differentiating into all tissue types except the placenta), and therefore the nuclei might not require as rigorous or complete genomic reprogramming for full-term development is required for as fully differentiated somatic cells.

ES-like cell lines have now been established from somatic cells via nuclear transfer in cows [15], mice [16-18], and humans [19]. These cell lines are considered to possess the same capacities for sufficient differentiation and self-renewal as those of conventional ES cell lines derived from normally fertilized embryos. To distinguish the two, the former are referred to as nuclear transfer ES (ntES) cell lines [20]. We previously showed that ntES cell lines are capable of differentiating into all three germ layers in vitro, or even into spermatozoa and oocytes, in chimeric mice produced by injection of ntES cells into the blastocoel of normal embryos [18]. This was the first time that ntES cells were demonstrated to have the same developmental potential as conventional ES cells (from fertilized embryo). Interestingly, ntES cell lines can be established successfully in certain inbred mouse strains [21], such as C57BL/6 and $\mathrm{C} 3 \mathrm{H} / \mathrm{He}$, but neither have ever been cloned successfully [8].

If ntES cells have the same potential as conventional ES cells, then in theory, the success rate of cloning mice from their nuclei should also be better than with somatic cells. We demonstrated previously that cloned mice can be generated from ntES cell nuclei, and that the success rate is similar to that for somatic cell cloning [18, 22]. However, because these studies used different donor mouse strains, further study is required to establish this point conclusively. In this study, we examined the production of cloned mice from somatic and ntES cell nuclei from the same mice to determine whether overall cloning efficiency can be improved using ntES cells.

\section{Materials and Methods}

\section{Animals}

F1 and F2 hybrid generation mice were used as nuclear donors to enhance the genetic diversity between individuals. Three male and two female (2 to 3 mo old) from the BD129 F1 [(C57BL/ $6 \times$ DBA/ 2) $\times 129 / \mathrm{Sv}$ ] and a male and a female from transgenic $(\mathrm{Tg})$ mice with a BDF2 $(\mathrm{BDF} 1 \times \mathrm{BDF} 1)$ background, carrying and expressing the gene for green fluorescent protein (GFP) [23], were used for both somatic cell cloning and the establishment of ntES cells. Enucleated BDF1 (C57BL/6 × DBA/2) strain oocytes were used as recipients for nuclear transfer. ICR females were used as surrogate mothers to carry the cloned embryos. All animals (obtained from SLC, Shizuoka, Japan, or bred in Riken) were maintained in accordance with the Animal Experiment Handbook at the Riken Center for Developmental Biology.

\section{Media}

Oocytes and embryos were cultured in KSOM medium (Specialty Media, Phillipsburg, NJ, USA) containing amino acids, glucose, and $1 \mathrm{mg} / \mathrm{ml}$ bovine serum albumin (BSA) at $37.5 \mathrm{C}$ under $5 \%$ $\mathrm{CO}_{2}$ in water-saturated air. Oocyte manipulations were carried out in Hepes-buffered CZB medium [24], pH7.4 (Hepes-CZB), at room temperature (25$29 \mathrm{C}$ ). $\mathrm{Ca}^{2+}$-free $\mathrm{CZB}$ containing $5 \mathrm{mM} \mathrm{SrCl}_{2}$ and 5 $\mu \mathrm{g} / \mathrm{ml}$ cytochalasin B (an inhibitor of actin polymerization) was used for oocyte activation [25].

\section{Isolation of cumulus cells and oocytes}

Mature BDF1 and BDF2 female mice were induced to superovulate by consecutive injections of equine chorionic gonadotrophin (eCG) (5 IU) and human chorionic gonadotrophin (hCG) (5 IU), which were given $48 \mathrm{~h}$ apart. Thirteen to $15 \mathrm{~h}$ after hCG injection, cumulus-oocyte complexes were collected from the oviducts, and cumulus cells were dispersed by a 10 min treatment with $0.1 \%(\mathrm{w} / \mathrm{v})$ bovine testicular hyaluronidase (300 USP units / $\mathrm{mg}$ ) in Hepes-CZB at $27 \mathrm{C}$. Approximately $2 \mu \mathrm{l}$ of BDF2 mouse cumulus cell suspension was transferred to $20 \mu \mathrm{l}$ Hepes-CZB containing $12 \%$ (w/ v) polyvinylpyrrolidone (PVP; Mr 360,000, Wako, Japan) and kept at room temperature for up to $3 \mathrm{~h}$ before injection. The molecular weight and concentration of the PVP in these experiments is 
apparently important; we have not so far been able to produce cloned mice when PVP with a molecular weight 360,000 is substituted with PVP at a lower molecular weight (unpublished observations).

\section{Isolation of tail-tip fibroblasts}

Tail tips of five BDF2 mice and one BD129F1 male mouse were isolated, freed of skin, cut into small pieces, divided between two $35 \mathrm{~mm}$ dishes, and incubated in $5 \mathrm{~mL}$ DMEM (Sigma- Aldrich, St. Louis, MO, USA) supplemented with $10 \%$ fetal calf serum (Sigma). When incubated for 10 to 14 days at $37.5 \mathrm{C}$ under $5 \% \mathrm{CO}_{2}$ in air, many fibroblasts were seen spreading over the surface of the dish. To detach the cells from the dish, they were treated for 10 min with $\mathrm{Ca}^{2+}-\mathrm{Mg}^{2+}$-free phosphate-buffered saline (PBS) containing $0.25 \%$ trypsin and $0.75 \mathrm{mM}$ ethylenediaminetetraacetic acid (EDTA). The suspension was pipetted for a few minutes to release the cells from the dish surface and centrifuged (1500 rpm $10 \mathrm{~min}$ ) to sediment the cells. The cells were then washed three times by the same centrifugation step using DMEM. Before injection, an aliquot of the cell suspension $(2 \mu \mathrm{l})$ was mixed with Hepes-CZB (about $20 \mu \mathrm{l}$ ) containing 12\% (w/ v) PVP and left at room temperature for up to $3 \mathrm{~h}$.

\section{Production of cloned offspring using adult somatic cells and ntES cells}

Enucleated BDF1 oocytes were injected individually with an adult tail tip, cumulus cell, or ntES cell nuclei $[2,4,18]$, activated using $\mathrm{Sr}^{2+}$ [25], cultured for $72 \mathrm{~h}$, and allowed to develop to morulae or blastocysts. When some cloned embryos had developed to the 2-cell stage or morulae/blastocyst stage, they were transferred to the oviducts or uteri of pseudopregnant foster mothers (ICR), which had been mated with vasectomized ICR males one or three days previously. All recipient females were euthanized at 19.5 days post-copulation (dpc), and their uteri were examined for the presence of fetuses and implantation sites.

\section{Establishment of ntES cell lines}

In this experiment, different pieces of tail or cumulus cells from the same female mice were used as nuclear donors. Cloned embryos were produced as described above, and when they reached the blastocyst stage, they were used to establish ntES cell lines as described previously [18, 21, 22]. All the established ntES cell lines were tested for alkaline phosphatase activity (a primordial germ cell marker) and the ability to form embryoid bodies (evidence of pluripotency).

\section{Statistical analyses}

Outcomes were evaluated using Chi-square tests, and $P<0.01$ was assumed to be statistically significant.

\section{Results}

Initially, we tried to produce cloned mice directly from the somatic cells of seven BD129F1 and BDF2 individuals (except for one mouse, M7, for which the cells were contaminated with bacteria). The success rates for production of full-term pups per transferred embryo varied between $0 \%$ and $15.6 \%$,

Table 1. Effect of cell sources for nucleus donors on the establishment of ntES cell lines and production of cloned animals Category 1: cloned mice were produced from both somatic and ntES cells

\begin{tabular}{|c|c|c|c|c|c|c|c|c|}
\hline \multicolumn{3}{|c|}{ Origin of donor nucleus } & \multirow[t]{2}{*}{$\begin{array}{c}\text { No. of } \\
\text { enucleated } \\
\text { oocytes }\end{array}$} & \multirow[t]{2}{*}{$\begin{array}{l}\text { No. of normally } \\
\text { activated } \\
\text { oocytes }\end{array}$} & \multirow[t]{2}{*}{$\begin{array}{c}\text { No. }(\%) \text { of oocytes } \\
\text { developing } \\
\text { to blastocyst* }\end{array}$} & \multirow[t]{2}{*}{$\begin{array}{l}\text { No. }(\%) \text { of } \\
\text { dead } \\
\text { fetuses }\end{array}$} & \multicolumn{2}{|c|}{$\begin{array}{c}\text { No. of successes } \\
\text { (\% oocytes activated) } \\
{[\% \text { blastocysts formed] }}\end{array}$} \\
\hline $\begin{array}{l}\text { Animal no. } \\
\text { genotype) }\end{array}$ & Cell source & $\begin{array}{c}\text { Tissue/Cell } \\
\text { line no. }\end{array}$ & & & & & $\begin{array}{c}\text { Live } \\
\text { offspring }\end{array}$ & $\begin{array}{c}\text { ntES cell } \\
\text { establishment }\end{array}$ \\
\hline M1(Male & Somatic cell & Fibroblast & 233 & 132 & $81(61.4)^{\mathrm{a}}$ & 6 & $4(3.0)[4.9]$ & - \\
\hline BD129F1) & Somatic cell & Fibroblast & 101 & 76 & $44(58)^{\mathrm{a}}$ & 一 & 一 & $25(32.9)$ [56.8] \\
\hline & ntES cell & M1-1 & 332 & 224 & $80(35.8)^{b}$ & 2 & $3(1.3)[3.8]$ & - \\
\hline & ntES cell & M1-2 & 132 & 65 & $13(20)^{b}$ & 4 & 0 & - \\
\hline & ntES cell & M1-3 & 151 & 91 & $15(17)^{\mathrm{b}}$ & 4 & 0 & - \\
\hline & ntES cell & M1-4 & 148 & 90 & $24(27)^{\mathrm{b}}$ & 3 & 0 & - \\
\hline
\end{tabular}

* Data were analyzed using the Chi-square test. $P<0.01$ between a and $\mathrm{b}$. 
Table 2. Effect of cell sources for nucleus donors on the establishment of ntES cell lines and production of cloned animals Category 2: cloned mice were only produced from somatic cells

\begin{tabular}{|c|c|c|c|c|c|c|c|c|}
\hline \multicolumn{3}{|c|}{ Origin of donor nucleus } & \multirow[t]{2}{*}{$\begin{array}{c}\text { No. of } \\
\text { enucleated } \\
\text { oocytes }\end{array}$} & \multirow[t]{2}{*}{$\begin{array}{l}\text { No. of normally } \\
\text { activated } \\
\text { oocytes }\end{array}$} & \multirow[t]{2}{*}{$\begin{array}{c}\text { No. (\%) of oocytes } \\
\text { developing } \\
\text { to blastocyst* }\end{array}$} & \multirow[t]{2}{*}{$\begin{array}{l}\text { No.of } \\
\text { dead } \\
\text { fetuses }\end{array}$} & \multicolumn{2}{|c|}{$\begin{array}{c}\text { No. of successes } \\
\text { (\% oocytes activated) } \\
{[\% \text { blastocysts formed] }}\end{array}$} \\
\hline $\begin{array}{l}\text { Animal no. } \\
\text { (genotype) }\end{array}$ & $\begin{array}{c}\text { Cell type } \\
\text { (tissue) }\end{array}$ & $\begin{array}{l}\text { Tissue/Cell } \\
\text { line no. }\end{array}$ & & & & & $\begin{array}{c}\text { Live } \\
\text { offspring }\end{array}$ & $\begin{array}{c}\text { ntES cell } \\
\text { establishment }\end{array}$ \\
\hline M2 (Male & Somatic cell & Fibroblast & 198 & 141 & $80(56.7)^{a}$ & 0 & $1(0.7)[1.3]$ & \\
\hline BD129F1) & Somatic cell & Fibroblast & 19 & 13 & $9(69)$ & - & - & $6(46.2)[66.7]$ \\
\hline & ntES cell & M2-1 & 140 & 121 & $9(7.4)^{b}$ & 0 & 0 & - \\
\hline & ntES cell & M2-2 & 108 & 61 & $22(36)^{c}$ & 0 & 0 & - \\
\hline F3 (Female & Somatic cell & Cumulus & 171 & 150 & $61(40.7)$ & 0 & $1(0.7)[1.6]$ & \\
\hline BD129F1) & Somatic cell & Cumulus & 81 & 18 & $11(61)^{d}$ & - & - & $9(50.0)[81.8]$ \\
\hline & ntES cell & F3-1 & 101 & 55 & $13(24)^{\mathrm{e}}$ & 0 & 0 & - \\
\hline & ntES cell & F3-2 & 102 & 75 & $18(24)^{\mathrm{e}}$ & 0 & 0 & - \\
\hline M4 (Male & Somatic cell & Fibroblast & 66 & 56 & $33(59)^{\mathrm{f}}$ & 0 & $5(8.9)[15.6]$ & - \\
\hline BDF2) & Somatic cell & Fibroblast & 64 & 41 & $29(71)^{\mathrm{f}}$ & - & - & $12(29.3)[41.4]$ \\
\hline & ntES cell & M4-1 & 132 & 94 & $28(30)^{g}$ & 0 & 0 & - \\
\hline & ntES cell & M4-2 & 124 & 83 & $16(19)^{g}$ & 0 & 0 & - \\
\hline
\end{tabular}

* Data were analyzed using the Chi-square test. $P<0.01$ between $\mathrm{a}$ and $\mathrm{b}, \mathrm{b}$ and $\mathrm{c}, \mathrm{d}$ and $\mathrm{e}, \mathrm{f}$ and $\mathrm{g}$.

with a mean rate of $3.0 \%$, which is the similar to the success rates in previous reports [2-11]. We established 68 ntES cell lines from all seven individual mice, with a high success rate $(16 \%$ to $82 \%$, mean 39\%). All established cell lines were positive for alkaline phosphatase staining and formed embryoid bodies, suggesting that these ntES cell lines would be pluripotent. In our previous reports $[18,21]$, the rates of establishing ntES cell lines were around $20 \%$, irrespective of mouse strain, sex, and cell type, but the BD129F1 and BDF2 strains were not used. To produce cloned mice from ntES cells in the present study, we carried out over 4000 nuclear transfers using 17 ntES cell lines derived from the seven donor mice, and obtained 41 cloned mice. The mean success rate $(4.8 \%)$ was slightly higher than that from the somatic cells $(3.0 \%)$.

When the results were analyzed for individual donor mice, they were categorized into four types. In category 1, cloned mice were obtained from both somatic and ntES cell nuclei (donor M1, Table 1). In category 2, clones were obtained only from somatic cell nuclei, but not from ntES cell nuclei (donors M2, F3, and M4; Table 2). In category 3, clones were obtained from ntES cell nuclei but not from somatic cell nuclei (donor F5; Table 3). In category 4, clones were not obtained from either cell type (donor F6; Table 4). The results for donor M7 were incomplete (the somatic cells were contaminated with bacteria) and provisionally placed in category 3 (Table 3 ). In this case, although the failure of cloned mice was due to a technical accident, we were still able to establish ntES cell lines. Though the rate of establishment of ntES cell lines was relatively low in category $3(16.7 \%$ vs. $41-82 \%)$, the success rate for producing clones from ntES cells was the highest $(7.4 \%$ vs. $0-3.8 \%)$. While no clones were obtained from category 4 (donor F6), ntES cell lines were established at a rate similar to the other donors.

The success rates for producing cloned mice from ntES cell nuclei differed between ntES cell lines, even when cell lines were derived from the same donor. Thus, for donor M1, only one (line M1-1) of 4 examined ntES cell lines contributed to produce clones, and its success rate $(3.8 \%)$ was similar to somatic cell cloning $(4.9 \%)$. For donor F5, we were unable to produce cloned mice from somatic cells or from the F5-1 ntES cell line, but one cloned mouse was obtained from the F5-2 line $(1.9 \%)$. However, nine cloned offspring were obtained $(8 \%)$, when ntES cell nuclei were used from the F53 line. 
Table 3. Effect of cell sources for nucleus donors on the establishment of ntES cell lines and production of cloned animals Category 3: cloned mice were only produced from ntES cells

\begin{tabular}{|c|c|c|c|c|c|c|c|c|}
\hline \multicolumn{3}{|c|}{ Origin of donor nucleus } & \multirow[t]{2}{*}{$\begin{array}{c}\text { No. of } \\
\text { enucleated } \\
\text { oocytes }\end{array}$} & \multirow[t]{2}{*}{$\begin{array}{l}\text { No. of normally } \\
\text { activated } \\
\text { oocytes }\end{array}$} & \multirow[t]{2}{*}{$\begin{array}{l}\text { No. }(\%) \text { of oocytes } \\
\text { developing } \\
\text { to blastocyst }\end{array}$} & \multirow[t]{2}{*}{$\begin{array}{l}\text { No. of } \\
\text { dead } \\
\text { fetuses }\end{array}$} & \multicolumn{2}{|c|}{$\begin{array}{c}\text { No. of successes } \\
\text { (\% oocytes activated) } \\
{[\% \text { blastocysts formed] }}\end{array}$} \\
\hline $\begin{array}{l}\text { Animal no. } \\
\text { (genotype) }\end{array}$ & $\begin{array}{l}\text { Cell type } \\
\text { (tissue) }\end{array}$ & $\begin{array}{l}\text { Tissue/Cell } \\
\text { line no. }\end{array}$ & & & & & $\begin{array}{c}\text { Live } \\
\text { offspring }\end{array}$ & $\begin{array}{c}\text { ntES cell } \\
\text { establishment }\end{array}$ \\
\hline \multirow{5}{*}{$\begin{array}{l}\text { F5 (Female } \\
\text { BDF2) }\end{array}$} & Somatic cell & Cumulus & 102 & 73 & $28(38)$ & 0 & 0 & - \\
\hline & Somatic cell & Cumulus & 124 & 110 & $53(48.2)^{\mathrm{a}}$ & - & - & $9(8.2)[17.0]$ \\
\hline & ntES cell & F5-1 & 154 & 91 & $33(36)$ & 1 & 0 & - \\
\hline & ntES cell & F5-2 & 334 & 232 & $54(23.3)^{\mathrm{b}}$ & 4 & $1(0.4)[1.9]$ & - \\
\hline & ntES cell & F5-3 & 450 & 330 & $113(34.2)$ & 8 & $9(2.7)[8.0]$ & - \\
\hline \multirow{4}{*}{$\begin{array}{l}\text { M7 (Male } \\
\text { BD129F1) }\end{array}$} & Somatic cell & Fibroblast & ND & - & - & - & - & - \\
\hline & Somatic cell & Fibroblast & 129 & 102 & $25(24.5)$ & - & - & $4(3.9)[16.0]$ \\
\hline & ntES cell & M7-1 & 309 & 237 & $90(38.0)$ & 6 & $7(3.0)[7.5]$ & - \\
\hline & ntES cell & M7-2 & 1081 & 653 & $227(34.8)$ & 8 & $21(3.2)[9.3]$ & - \\
\hline
\end{tabular}

${ }^{*}$ Data were analyzed using the Chi-square test. $P<0.01$ between a and $b$.

For donor M7, somatic cell cloning experiments could not be conducted because of contamination.

Table 4. Effect of cell sources for nucleus donors on the establishment of ntES cell lines and production of cloned animals Category 4: Cloned mice were not produced from somatic cells or ntES cells

\begin{tabular}{|c|c|c|c|c|c|c|c|c|}
\hline \multicolumn{3}{|c|}{ Origin of donor nucleus } & \multirow[t]{2}{*}{$\begin{array}{c}\text { No. of } \\
\text { enucleated } \\
\text { oocytes }\end{array}$} & \multirow[t]{2}{*}{$\begin{array}{c}\text { No. of normally } \\
\text { activated } \\
\text { oocytes }\end{array}$} & \multirow[t]{2}{*}{$\begin{array}{c}\text { No. (\%) of oocytes } \\
\text { developing } \\
\text { to blastocyst }\end{array}$} & \multirow[t]{2}{*}{$\begin{array}{l}\text { No. of } \\
\text { dead } \\
\text { fetuses }\end{array}$} & \multicolumn{2}{|c|}{$\begin{array}{c}\text { No. of successes } \\
\text { (\% oocytes activated }) \\
{[\% \text { blastocysts formed }]}\end{array}$} \\
\hline (genotype) & (tissue) & line no & & & & & $\begin{array}{c}\text { Live } \\
\text { offspring }\end{array}$ & $\begin{array}{c}\text { ntES cell } \\
\text { establishment }\end{array}$ \\
\hline \multirow{4}{*}{$\begin{array}{c}\text { F6 (Female } \\
\text { BD129F1) }\end{array}$} & Somatic cell & Cumulus & 187 & 140 & $86(61.4)^{\mathrm{a}}$ & 0 & 0 & - \\
\hline & Somatic cell & Cumulus & 11 & 8 & $5(63)$ & - & 一 & $3(37.5)[60.0]$ \\
\hline & ntES cell & F6-1 & 147 & 113 & $36(31.9)^{\mathrm{b}}$ & 0 & 0 & - \\
\hline & ntES cell & F6-2 & 108 & 69 & $21(30)^{\mathrm{b}}$ & 0 & 0 & - \\
\hline
\end{tabular}

*Data were analyzed using the Chi-square test. $P<0.01$ between a and $b$.

\section{Discussion}

The main objective of this study was to evaluate whether the success rate of producing cloned mice from ntES cell lines is higher than when using somatic cell nuclei from the same donor. We predicted that it would be higher since previous studies using different mouse strains showed better success rates using ES cell nuclei from normally fertilized embryos than from somatic cells; moreover, ntES and ES cells have very similar characteristics [18, 21].

Previously, we demonstrated that cloned mice can be generated from the nuclei of ntES cells [18]. We have also reported that mice can be cloned from the ICR strain using ntES cell nuclei [22], although it is very difficult to generate clones from adult somatic cell nuclei in this strain [26, 27]. However, the success rate in that study of ntES cloning was very low, and cloned pups were only obtained from one ntES cell line [22]. Thus, if it is difficult to produce cloned mice from somatic cell nuclei in a particular strain, it would also be difficult to produce clones via a second nuclear transfer from ntES cell nuclei $[18,22]$. However, in those previous experiments, the somatic and ntES cell cloning studies used different individual mice, so a direct comparison of success rates was not possible. Therefore, in this study, somatic cells from the same donor mice were used for somatic clone production, establishment of ntES cell lines, and the following clone production from established ntES cells.

As a result of this study, the mean success rates were unexpectedly similar between ntES cell and somatic cell nuclei, and showed high variability 
between donors in both cloning approaches. Only five of the 17 examined ntES cell lines contributed to cloned mice successfully. Thus, conversion from somatic cells to ntES cells does not increase the overall success rate of cloning. Moreover, the potential of donor nuclei for creating full-term development differed among ntES cell lines, even when the cell lines were derived from the same individual at the same time. For example, M1-1 ntES cell line showed a success rate similar to somatic cell cloning, whereas three other cell lines (M1-2 to M1-4) failed to form clone pups. The ntES cell lines from donor F5 showed more variation, and no cloned mice were born from nuclei of either somatic or F5-1 ntES cell nuclei. For this donor mouse, only one cloned mouse $(1.9 \%)$ was born from the F5-2 ntES cell line. On the other hand, the F5-3 ntES cell line showed a high success rate ( $8 \%$ ). Thus, ntES cell lines shows different potential, not only according to their genetic background, but also between each line, even those derived from the same individuals. This suggests that these differences were caused by epigenetic differences between donor cell nuclei, even among those from the same individual. We also noted that when the ntES cell establishment rate was lower, the success rate of cloned mice from these ntES cells was actually higher (see category 3 ).

Previously, we demonstrated that most (up to $80 \%)$ ntES cells showed normal karyotypes and germ line transmission, which confirmed their pluripotency [21]. The characteristics of these ntES cells were nearly identical to those of ES cells derived from normally fertilized embryos. It is possible that, most of the somatic nuclei that were transferred to enucleated oocytes might be incompletely reprogrammed, whereas they still showed normal developmental potential to the blastocyst stage [28, 29], and ntES cells have been established from incompletely reprogrammed blastocysts. Therefore, ntES cells may still retain some somatic-style epigenetic status, even if we have never detected any obvious difference between ntES and ES cells to date. The abnormal epigenetic status of the nucleus by incomplete reprogramming may not be visible even when ntES cells are transmitted via chimeric mice [18, 22]. However, the abnormal condition of the nucleus after first nuclear transfer may affect the development of clones via a second nuclear transfer. In other words, most of the ntES cell lines that were studied here may have different potential than ordinary ES cells, probably because of the imperfect nuclear epigenetic status of their nucleus. Further investigation is clearly needed to elucidate this.

In our previous work, the overall rate of ntES cell line establishment ranged from $9 \%$ to $18 \%[18,21]$. In the current study, it ranged from $16 \%$ to $82 \%$, with a mean of $39 \%$. This improvement could be explained by better nuclear transfer and ntES cell derivation techniques, such as a newly modified medium [30]. However, different mouse genotypes (either different genotypes or different supplying companies) and-possibly-increased skill of the researchers [31] may have affected the present results. Blelloch et al. [32] reported that $44 \%-57 \%$ of cloned blastocysts derived from embryonic carcinoma (EC) and ES cell nuclei could be used to establish ntES cell lines successfully, and suggested that the epigenetic state of the EC/ES cell genomes might be more efficiently reprogrammed than somatic cell genomes [32]. Our results here showed similar success rates from somatic cell nuclei as shown in that report. However, caution is required when comparing results between laboratories, as individual skill levels and laboratory environments will vary and affect the success rate.

In conclusion, the production of cloned mice from ntES cell nuclei in this series was no better than from somatic cells. However, we succeeded in cloning mice from three out of seven individuals via ntES cells. Thus, establishing ntES cell lines gives a better overall chance to clone mice from individual donors. Further, ntES cells will divide indefinitely and are easily cryopreserved. Therefore, for cloning valuable individual mice, we recommend that laboratories establish ntES cells simultaneously with the use of somatic cells as nuclear donors.

\section{Acknowledgments}

We thank Dr. J. Cummins for critical and useful comments on the manuscript. We are grateful to the Laboratory for Animal Resources and Genetic Engineering for housing of the mice. Financial support for this research was provided by Grantsin-Aid for Creative Scientific Research (13GS0008), Scientific Research in Priority Areas (15080211), Young Scientists A (15681014), and a project for the 
realization of regenerative medicine (the research field for the technical development of stem cell manipulation) to T.W., and a grant for the 21st
Century COE Program to M. M. from the Ministry of Education, Science, Sports, Culture and Technology of Japan.

\section{References}

1. Willadsen SM. Nuclear transplantation in sheep embryos. Nature 1986; 320: 63-65.

2. Wakayama T, Perry ACF, Zuccotti M, Johnson KR, Yanagimachi R. Full-term development of mice from enucleated oocytes injected with cumulus cell nuclei. Nature 1998; 394: 369-374.

3. Wakayama T, Shinkai $Y$, Tamashiro KL, Niida $H$, Blanchard DC, Blanchard RJ, Ogura A, Tanemura K, Tachibana M, Perry AC, Colgan DF, Mombaerts P, Yanagimachi R. Cloning of mice to six generations. Nature 2000; 407: 318-319.

4. Wakayama T, Yanagimachi R. Cloning of male mice from adult tail-tip cells. Nat Genet 1999; 22: 127-128.

5. Ogura A, Inoue K, Ogonuki N, Noguchi A, Takano K, Nagano R, Suzuki O, Lee J, Ishino F, Matsuda J. Production of male cloned mice from fresh, cultured, and cryopreserved immature Sertoli cells. Biol Reprod 2000; 62: 1579-1584.

6. Inoue $\mathbf{K}$, Wakao $\mathbf{H}$, Ogonuki $\mathbf{N}$, Miki $\mathbf{H}$, Seino $\mathbf{K}$, Nambu-Wakao R, Noda S, Miyoshi H, Koseki H, Taniguchi M, Ogura A. Generation of cloned mice by direct nuclear transfer from natural killer T cells. Curr Biol 2005; 15: 1114-1118.

7. Miki H, Inoue K, Kohda T, Honda A, Ogonuki N, Yuzuriha M, Mise N, Matsui Y, Baba T, Abe K, Ishino F, Ogura A. Birth of mice produced by germ cell nuclear transfer. Genesis 2005, 41: 81-86.

8. Wakayama T, Yanagimachi R. Mouse cloning with nucleus donor cells of different age and type. $\mathrm{Mol}$ Reprod Dev 2001; 58: 376-383.

9. Wakayama T, Yanagimachi R. Effect of cytokinesis inhibitor, DMSO and the timing of oocyte activation on mouse cloning using cumulus cell nuclei. Reproduction 2001; 122: 49-60.

10. Kishikawa H, Wakayama T, Yanagimachi R. Comparison of oocyte-activating agents for mouse cloning. Cloning 1999; 1: 153-159.

11. Wakayama S, Cibelli JB, Wakayama T. Effect of timing of the removal of oocyte chromosomes before or after injection of somatic nucleus on development of NT embryos. Cloning Stem Cells 2003; 5: 181-189.

12. Wakayama T, Rodriguez I, Perry ACF, Yanagimachi R, Mombaerts P. Mice cloned from embryonic stem cells. Proc Natl Acad Sci USA 1999; 96: 14984-14989.

13. Rideout WM 3rd, Wakayama T, Wutz A, Eggan K, Jackson-Grusby L, Dausman J, Yanagimachi R,
Jaenisch R. Generation of mice from wild-type and targeted ES cells by nuclear cloning. Nat Genet 2000; 24: 109-110.

14. Inoue K, Ogonuki N, Mochida K, Yamamoto $\mathbf{Y}$, Takano K, Kohda T, Ishino F, Ogura A. Effects of donor cell type and genotype on the efficiency of mouse somatic cell cloning. Biol Reprod 2003; 69:1394-1400.

15. Cibelli JB, Stice SL, Golueke PJ, Kane JJ, Jerry J, Blackwell C, Ponce de Leon FA, Robl JM. Transgenic bovine chimeric offspring produced from somatic cell-derived stem-like cells. Nat Biotechnol 1998; 16: 642-646.

16. Munsie MJ, Michalska AE, O'Brien CM, Trounson AO, Pera MF, Mountford PS. Isolation of pluripotent embryonic stem cells from reprogrammed adult mouse somatic cell nuclei. Curr Biol 2000; 10: 989-992.

17. Kawase E, Yamazaki Y, Yagi T, Yanagimachi R, Pedersen RA. Mouse embryonic stem (ES) cell lines established from neuronal cell-derived cloned blastocysts. Genesis 2000; 28: 156-163.

18. Wakayama T, Tabar V, Rodriguez I, Perry ACF, Studer L, Mombaerts P. Differentiation of embryonic stem cell lines generated from adult somatic cells by nuclear transfer. Science 2001; 292: 740-743.

19. Hwang WS, Ryu YJ, Park JH, Park ES, Lee EG, Koo JM, Jeon HY, Lee BC, Kang SK, Kim SJ, Ahn C, Hwang JH, Park KY, Cibelli JB, Moon SY. Evidence of a pluripotent human embryonic stem cell line derived from a cloned blastocyst. Science 2004; 303: 1669-1674.

20. Mombaerts P. Therapeutic cloning in the mouse. Proc Natl Acad Sci USA. 2003; 100: 11924-11925.

21. Wakayama S, Ohta H, Kishigami S, Van Thuan N, Hikichi T, Mizutani E, Miyake M, Wakayama T. Establishment of male and female nuclear transfer embryonic stem cell lines from different mouse strains and tissues. Biol Reprod 2005; 72: 932-936.

22. Wakayama S, Kishigami S, Thuan NV, Ohta $H$, Hikichi T, Mizutani E, Yanagimachi R, Wakayama T. Propagation of an infertile hermaphrodite mouse lacking germ cells, using nuclear transfer and embryonic stem cell technology. Proc Natl Acad Sci USA 2005; 102: 29-33.

23. Okabe M, Ikawa M, Kominami K, Nakanishi T, Nishimune Y. 'Green mice' as a source of ubiquitous green cells. FEBS Lett 1997; 407: 313-319. 
24. Chatot CL, Ziomek A, Bavister BD, Torres I. An improved culture medium supports development of random-bred 1-cell mouse embryos. J Reprod Fertil 1989; 86: 7679-7688.

25. Bos-Mikich A, Whittingham DG, Kones KT. Meiotic and Mitotic $\mathrm{Ca}^{2+}$ oscillations affect cell composition in resulting blastocysts. Dev Biol 1997; 182: 172-179.

26. Saito M, Saga A, Matsuoka H. Production of a cloned mouse by nuclear transfer from a fetal fibroblast cell of a mouse closed colony strain. Exp Anim 2004; 53: 467-469.

27. Ono Y, Shimozawa N, Ito M, Kono T. Cloned mice from fetal fibroblast cells arrested at metaphase by a serial nuclear transfer. Biol Reprod 2001, 64: 44-50.

28. Gao S, Chung YG, Williams JW, Riley J, Moley K, Latham KE. Somatic cell-like features of cloned mouse embryos prepared with cultured myoblast nuclei. Biol Reprod 2003; 69: 48-56.

29. Boiani M, Eckardt S, Scholer HR, McLaughlin KJ. Oct4 distribution and level in mouse clones: consequences for pluripotency. Genes Dev 2002; 16: 1209-1219.

30. Ogawa K, Matsui H, Ohtsuka S, Niwa H. A novel mechanism for regulating clonal propagation of mouse ES cells. Genes Cells 2004; 9: 471-477.

31. Perry AC, Wakayama T. Untimely ends and new beginnings in mouse cloning. Nat Genet 2002; 30: 243-244.

32. Blelloch $\mathrm{RH}$, Hochedlinger $\mathrm{K}$, Yamada $\mathrm{Y}$, Brennan C, Kim M, Mintz B, Chin L, Jaenisch R. Nuclear cloning of embryonal carcinoma cells. Proc Natl Acad Sci USA 2004; 101: 13985-13990. 